\title{
ЗМІНА ДЕЯКИХ ПОКАЗНИКІВ АНТИОКСИДАНТНОЇ СИСТЕМИ В ЩУРІВ З ТОКСИЧНИМ УРАЖЕННЯМ АЦЕТАМІНОФЕНОМ НА ТЛІ ЦУКРОВОГО ДІАБЕТУ 2 ТИПУ
}

Вступ. Ацетамінофрен чинить дозозалежну дію на печінку, ступінь ураження якої залежить від концентрації цього препарату в плазмі. При прийманні великої його кількості (випадково або із суїцидальними намірами) в печінці виникають масивні центролобулярні некрози. Цукровий діабетє також одним із фракторів ризику розвитку цирозу печінки.

Мета дослідження - вивчити вплив ацетамінофену на тлі цукрового діабету 2 типу на основні показники антиоксидантної системи в гомогенаті печінки та плазмі крові щурів у часовій динаміці.

Методи дослідження. Було проведено 2 серії експерименту. В першій токсичне ураження ацетамінофеном викликали шляхом одноразового внутрішньошлункового введення тваринам суспензіі ацетамінофрену в 2 \% розчині крохмалю у дозі 1250 мг/кг маси тіла (1/2 LD 50 ), у другій - чієї ж суспензії у дозі 55 мг/кг. Негенетичну фрорму експериментального цукрового діабету 2 типу моделювали шляхом одноразового внутрішньочеревного введення розчину стрептозотоцину з розрахунку 65 мг/кг, який розводили цитратним буфрером ( $\mathrm{pH}$ 4,5) з попереднім інтраперитонеальним уведенням нікотинаміду в дозі 230 мг/ке. Для контрольної групи використовували щурів з тією ж масою тіла, яким вводили аналогічний об'єм розчинника (цитратний бусрер з $\mathrm{pH} 4,5$ ).

Результати й обговорення. Результати експерименту показали, що більшу токсичність в організмі піддослідних тварин викликало введення ацетамінофрену на тлі цукрового діабету 2 типу.

Висновок. Токсичне ураження ацетамінофреном на тлі цукрового діабету 2 типу супроводжується суттєвими порушеннями фрерментних компонентів системи антиоксидантного захисту, що мають компенсаторний характер і спрямовані на знешкодження продуктів вільнорадикального окиснення.

КЛЮЧОВІ СЛОВА: ацетамінофен; церулоплазмін; каталаза; супероксиддисмутаза; пероксидазна активність крові; цукровий діабет.

ВСТУП. Найпотужнішими ксенобіотиками, 3 якими повсюдно стикається людина, є ліки, що спричиняють виникнення 40 \% гепатитів, і це не випадково, оскільки основна орункція печінки полягає в знешкодженні отрут. Тому даний орган найбільше страждає від великих доз препаратів $[2,3]$. Ацетаміносрен чинить дозозалежну дію на печінку, ступінь ураження якої залежить від концентрації цього препарату в плазмі $[4,12]$. При прийманні великої його кількості (випадково або із суїцидальними намірами) в печінці виникають масивні центролобулярні некрози. Цукровий діабет (ЦД) є також одним із фракторів ризику розвитку цирозу печінки [1].

Будь-який вид взаємодії ліків змінює кінцевий фрармакологічний ефект їх комбінації. Як результат можливе посилення дії одного чи обох (с) О. Б. Фурка, І. Б. Івануса, М. М. Михалків, І. М. Кліщ, 2017. компонентів комбінації, аж до появи токсичного еоректу [5].

Мета дослідження - вивчити стан антиоксидантної системи в щурів з токсичним ураженням ацетаміноореном на тлі цукрового діабету 2 типу.

МЕТОДИ ДОСЛІДЖЕННЯ. ДОсліДИ виконували на білих статевозрілих щурах масою $(200 \pm 20)$ г, яких утримували на стандартному раціоні віварію при вільному доступі до води.

Було проведено 2 серії експерименту. В першій токсичне ураження ацетамінофеном викликали шляхом одноразового внутрішньошлункового введення тваринам суспензії ацетамінофену в $2 \%$ розчині крохмалю у дозі 1250 мг/кг маси тіла (1/2 LD $\left.{ }_{50}\right)$, у другій - цієї ж суспензії у дозі 55 мг/кг, що відповідає вищій терапевтичній дозі, протягом 7 діб. Негенетичну 
фрорму експериментального цукрового діабету 2 типу моделювали за методикою S. Islam, H. Choi $[13,14]$ шляхом одноразового внутрішньочеревного введення розчину стрептозотоцину ("Sigma", США) з розрахунку 65 мг/кг, який розводили цитратним бусрером ( $\mathrm{pH} 4,5) 3$ попереднім (за 15 хв) інтраперитонеальним уведенням нікотинаміду в дозі 230 мг/кг. Для контрольної групи використовували щурів з тією ж масою тіла, яким вводили аналогічний об'єм розчинника (цитратний буфрер з рН 4,5).

У першій серії експерименту піддослідних щурів поділили на чотири групи: 1-ша - інтактні (контроль); 2-га-уражені ацетаміносреном одноразово; 3-тя - тварини, яким вводили стрептозотоцин; 4-та - уражені ацетамінофреном одноразово після введення стрептозотоцину. В другій серії піддослідних тварин також поділили на чотири групи: 1-ша - інтактні (контроль); 2-га уражені ацетамінофеном протягом 7 діб; 3-тя тварини, яким вводили стрептозотоцин; 4-та уражені ацетамінофреном протягом 7 діб після введення стрептозотоцину.

Тварин виводили з експерименту на 1-шу, 3-тю, 5-ту і 7-му доби з моменту припинення ураження шляхом евтаназії за умов тіопенталового наркозу. Всі досліди на щурахпроводили відповідно до Науково-практичних рекомендацій з утримання лабораторних тварин та роботи з ними [6].

Загальну пероксидазну активність крові (ПАК) визначали за методом Т. Попова [10]. Рівень церулоплазміну (ЦП) визначали за методом [7]. Активність каталази (КT) досліджували за методикою М. А. Королюка та ін. [8]. Активність супероксиддисмутази (СОД) визначали за мето- дикою [11]. Кількісні показники обробляли статистично. Результати досліджень піддавали статистичному аналізу [9] за допомогою статистичної програми STATISTICA з використанням параметричного критерію Стьюдента і непараметричного критерію Вілкоксона для зв'язаних вибірок. Зміни вважали достовірними при p $\leq 0,05$.

РЕЗУЛЬТАТИ Й ОБГОВОРЕННЯ. АНТИОКСИдантна система - це потужний механізм, що запобігає розвитку лавиноподібних вільнорадикальних та перекисних реакцій в організмі. Дана система клітин організму діє завдяки наявності сполук - антиоксидантів, у складі яких міститься рухливий атом гідрогену, що не дуже міцно з'єднаний з карбоном (С-H) або сульсруром (S-H). У результаті реакцій молекул-антиоксидантів та вільних радикалів утворюються радикали антиоксидантів, які не є потужними окисниками й не можуть продовжувати перебіг вільнорадикальних реакцій окиснення, тобто вони обривають ці ланцюги. Радикали молекул-антиоксидантів виводяться з організму у вигляді кінцевих продуктів у результаті взаємодії з молекулами інших антиоксидантів.

Антиоксиданти можуть знешкоджувати вільні радикали ще до моменту реалізації їх руйнівної дії. Таким чином, основним завданням антиоксидантної системи є зменшення кількості вільних радикалів до мінімально можливого рівня.

Як показали отримані результати (табл. 1), рівень церулоплазміну в першій серії експерименту на 1-шу добу знизився на 19,6 \% (2-га група тварин), у щурів із ЦД 2 типу (3-тя група тварин) - на 5,8\%. Застосування $1 / 2 \mathrm{LD}_{50}$

Таблиця 1 - Динаміка вмісту церулоплазміну, загальної пероксидазної активності крові, активності каталази і супероксиддисмутази в плазмі крові щурів за умов

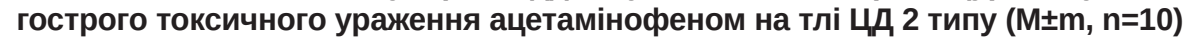

\begin{tabular}{|c|c|c|c|c|c|}
\hline \multirow{2}{*}{ Група тварин } & \multirow{2}{*}{ Показник } & \multicolumn{4}{|c|}{ Час після введення ацетамінофрену, доба } \\
\hline & & 1-ша & 3-тя & 5-та & 7-ма \\
\hline \multirow[t]{4}{*}{ Контроль } & ЦП, мг/л & \multirow{2}{*}{\multicolumn{4}{|c|}{$\begin{array}{c}273,82 \pm 3,32 \\
0,23 \pm 0,01\end{array}$}} \\
\hline & КТ, мкат/л & & & & \\
\hline & СОД, ум. од./л & \multicolumn{4}{|c|}{$1,23 \pm 0,02$} \\
\hline & ПАК, МКМОЛЬ/Л & \multicolumn{4}{|c|}{$288,64 \pm 4,27$} \\
\hline \multirow{4}{*}{$\begin{array}{l}\text { Ацетамінофен } \\
\text { одноразово }\end{array}$} & ЦП, мг/л & $220,15 \pm 12,09$ & $242,61 \pm 0,68^{*}$ & $253,02 \pm 16,21$ & $270,54 \pm 13,48$ \\
\hline & КТ, мкат/л & $0,91 \pm 0,02^{*}$ & $0,89 \pm 0,01^{*}$ & $0,86 \pm 0,16^{*}$ & $0,83 \pm 0,07^{*}$ \\
\hline & СОД, ум. од./л & $2,15 \pm 0,27^{*}$ & $2,07 \pm 0,28^{*}$ & $1,91 \pm 0,26^{*}$ & $1,84 \pm 0,20^{\star}$ \\
\hline & ПАК, МКМОЛЬ/Л & $491,84 \pm 6,27^{*}$ & $508,87 \pm 6,83^{*}$ & $530,67 \pm 6,93^{*}$ & $549,70 \pm 8,61^{*}$ \\
\hline \multirow[t]{4}{*}{ ЦД 2 типу } & ЦП, мг/л & $257,94 \pm 9,02^{*}$ & $275,46 \pm 0,44$ & $299,29 \pm 11,73$ & $307,23 \pm 10,72^{\star}$ \\
\hline & КТ, мкат/л & $0,32 \pm 0,04$ & $0,29 \pm 0,01^{*}$ & $0,27 \pm 0,03$ & $0,25 \pm 0,02$ \\
\hline & СОД, ум. од./л & $1,59 \pm 0,16$ & $1,50 \pm 0,15$ & $1,42 \pm 0,25$ & $1,35 \pm 0,15$ \\
\hline & ПАК, МКМОЛЬ/Л & $618,27 \pm 4,62^{\star}$ & $635,30 \pm 3,42^{*}$ & $659,25 \pm 5,33^{*}$ & $682,63 \pm 6,28^{\star}$ \\
\hline \multirow{4}{*}{$\begin{array}{l}\text { Ацетамінофен } \\
\text { на тлі цд } \\
2 \text { типу }\end{array}$} & ЦП, мг/л & $175,52 \pm 7,25^{\star *}$ & $192,22 \pm 0,73^{\text {* }}$ & $204,00 \pm 10,98^{\star \#}$ & $223,71 \pm 14,24^{* \#}$ \\
\hline & КТ, мкат/л & $1,21 \pm 0,18^{\star \#}$ & $1,19 \pm 0,01^{\text {*\# }}$ & $1,16 \pm 0,20^{*}$ & $1,13 \pm 0,10^{* \#}$ \\
\hline & СОД, ум. од./л & $1,82 \pm 0,15$ & $1,73 \pm 0,25$ & $1,67 \pm 0,24$ & $1,61 \pm 0,19$ \\
\hline & ПАК, мКМОЛЬ/Л & $807,33 \pm 12,03^{\star \#}$ & $823,78 \pm 4,49^{* *}$ & $844,27 \pm 6,93^{* \#}$ & $879,20 \pm 6,51^{* \#}$ \\
\hline
\end{tabular}

Примітки. Тут і в таблицях 2-4:

1. * - різниця достовірна відносно контрольних тварин.

2. * - різниця достовірна відносно тварин, уражених ацетамінофеном. 
ацетамінофену на тлі Цд 2 типу (4-та група тварин) призвело до ще більшого зменшення даногопоказника-на 35,9\% відповідно до контрольної групи щурів. Отже, результати експерименту свідчать про те, що більшу токсичність в організмі піддослідних тварин викликало введення ацетамінофену на тлі ЦД 2 типу. В подальшому експерименті рівень ЦП зазнавав поступового відновлення (1-ша та 4-та групи щурів). Однак у 3-й групі піддослідних тварин цей показник зріс на 9,3 та 12,2 \% на 5-ту і 7-му доби експерименту, що, ймовірно, пов'язано з меншим ураженням печінки й активацією захисних процесів. На тлі зниження вмісту ЦП виявлено зростання загальної пероксидазної активності крові в щурів 2-ї та 3-ї груп в 1,7 і 2,14 раза, а в щурів 4-ї групи у 2,79 раза відповідно до контрольної групи тварин на 1-шу добу експерименту. Максимальне підвищення даного показника було відмічено на 7-му добу: у тварин 2-ї та 3-ї груп ПАК збільшилася в 1,9 і 2,36 раза, а в щурів 4-ї групи - у 3,04 раза. На нашу думку, таке інтенсивне зростання показника свідчить про збільшення кількості $\mathrm{H}_{2} \mathrm{O}_{2}$, на руйнування якого спрямовані пероксидази.

Активність каталази у плазмі крові піддослідних тварин різко збільшувалася протягом усього експерименту (табл. 1). Максимальне підвищення даного показника відзначено на 1-шу добу: у тварин 2-ї та 4-ї груп - у 3,95 і 5,25 раза, тоді як у щурів 3-ї групи - на 37,9%. В інші доби експерименту активність каталази в плазмі крові поступово знижувалась. Аналогічні зміни відбувалися при визначенні активності супероксиддисмутази. Таке різке підвищення активності КТ і СОД, можливо, пов'язане із знешкодженням збільшеної кількості вільних радикалів, які утворюються при будь-якій патології.

Активність каталази в гомогенаті печінки зазнала зниження на 1-шу добу експерименту у тварин всіх груп (табл. 2). У 2-й групі щурів, яким вводили ацетамінофрен одноразово, вона зменшилась на 51,7 \%, тоді як у тварин 3-ї групи при введенні стрептозотоцину - на 1,6 \%. Максимальне зниження відмічено в щурів 4-ї групи, уражених ацетамінофеном на тлі ЦД 2 типу, - на 63,9 \% відповідно до контрольної групи тварин. В інші доби експерименту спостерігали підвищення даного показника. Зниження активності КТ у гомогенаті печінки ми пов'язуємо з викидом срерменту в кров (активність КТ у плазмі крові при цьому зростала).

Аналогічну ситуацію спостерігали і при визначенні активності супероксиддисмутази. Так, у гомогенаті печінки тварин 2-ї та 4-ї груп вона зменшилася на 1-шу добу експерименту на 57,3 і 57,5 \%, тоді як на 7-му добу даний показник у вищенаведених групах знизився на 39,7 та 39,9\%. Ймовірно, при ЦД 2 типу печінка зазнає меншого ураження, тому в щурів 3-ї групи активність СОД підвищилася на 1-шу добу в 3,2 раза, тоді як на 3-тю, 5-ту і 7-му доби - в 3,37, 3,51, 3,62 раза.

Таблиця 2 - Динаміка активності каталази і супероксиддисмутази в гомогенаті печінки щурів

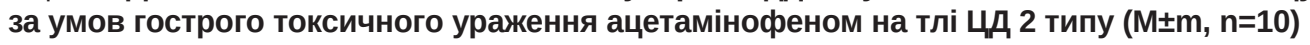

\begin{tabular}{|c|c|c|c|c|c|}
\hline \multirow{2}{*}{ Група тварин } & \multirow{2}{*}{ Показник } & \multicolumn{4}{|c|}{ Час після введення ацетамінофрену, доба } \\
\hline & & 1-ша & 3-тя & 5-та & 7-ма \\
\hline \multirow[t]{2}{*}{ Контроль } & КТ, мкат/кг & \multicolumn{4}{|c|}{$59,53 \pm 1,43$} \\
\hline & СОД, ум. од./кг & \multicolumn{4}{|c|}{$4,09 \pm 0,13$} \\
\hline \multirow{2}{*}{$\begin{array}{l}\text { Ацетамінофен } \\
\text { одноразово }\end{array}$} & КТ, мкат/кг & $28,75 \pm 0,80^{*}$ & $32,44 \pm 0,90^{*}$ & $37,62 \pm 2,79 *$ & $42,45 \pm 1,64^{*}$ \\
\hline & СОД, ум. од./кг & $1,74 \pm 0,18^{\star}$ & $1,94 \pm 0,32^{\star}$ & $2,24 \pm 0,23^{*}$ & $2,46 \pm 0,33^{\star}$ \\
\hline \multirow[t]{2}{*}{ ЦД 2 типу } & КТ, мкат/кг & $58,58 \pm 1,61^{*}$ & $61,20 \pm 0,84$ & $65,79 \pm 2,52^{*}$ & $72,39 \pm 2,09 *$ \\
\hline & СОД, ум. од./кг & $13,10 \pm 0,39 *$ & $13,79 \pm 1,17^{*}$ & $14,34 \pm 1,77^{*}$ & $14,82 \pm 1,43^{*}$ \\
\hline \multirow{2}{*}{$\begin{array}{l}\text { Ацетамінофрен } \\
\text { на тлі ЦД } 2 \text { типу }\end{array}$} & КТ, мкат/кг & $21,49 \pm 1,12^{\star \#}$ & $25,72 \pm 0,85^{\star \#}$ & $29,53 \pm 2,18^{\star \#}$ & $31,91 \pm 1,84^{\text {*\# }}$ \\
\hline & СОД, ум. од./кг & $1,73 \pm 0,20 *$ & $1,99 \pm 0,21^{*}$ & $2,19 \pm 0,23^{*}$ & $2,45 \pm 0,34^{*}$ \\
\hline
\end{tabular}

Як і в першій серії експерименту, в другій серії у тварин, яким вводили ацетамінофен у максимальній терапевтичній дозі протягом 7 діб, було відмічено, що впродовж 7 діб рівень церулоплазміну (табл. 3) зменшувався відносно контрольних щурів протягом усього експерименту. А також загальна пероксидазна активність крові зростала протягом усіх діб експерименту.

Як видно з таблиці 3, активність каталази і супероксиддисмутази у плазмі крові піддослідних тварин зазнала максимального зростання на 1-шу добу експерименту. Активність каталази у плазмі крові щурів 2-ї групи підвищилась у
2,39 раза, тоді як у 4-й групі - у 3,43 раза. На 3-тю, 5-ту і 7-му доби активність ферменту поступово знижувалась. Аналогічні зміни відмічено при визначенні активності супероксиддисмутази у плазмі крові. Необхідно відзначити, що зміни цих показників були менш виражені, ніж у першій серії експерименту, що пов'язано зі зниженням дози ацетаміносрену, а отже, із зменшенням руйнівної дії на організм токсикантів.

Активність каталази і супероксиддисмутази (табл. 4) в гомогенаті печінки знижувалася протягом усього експерименту в усі доби. Ці зміни також були менш виражені, ніж у першій серії експерименту. 
Таблиця 3 - Динаміка вмісту церулоплазміну, загальної пероксидазної активності крові, активності каталази і супероксиддисмутази в плазмі крові щурів за дії ацетамінофену

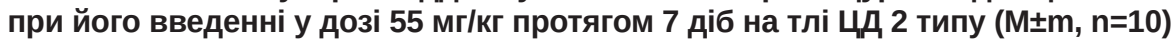

\begin{tabular}{|c|c|c|c|c|c|}
\hline \multirow{2}{*}{ Група тварин } & \multirow{2}{*}{ Показник } & \multicolumn{4}{|c|}{ Час після введення ацетамінофену, доба } \\
\hline & & 1-ша & 3-тя & 5-та & 7-ма \\
\hline \multirow[t]{4}{*}{ Контроль } & ЦП, мг/л & \multicolumn{4}{|c|}{$273,82 \pm 3,32$} \\
\hline & КТ, мкат/л & \multicolumn{4}{|c|}{$0,23 \pm 0,01$} \\
\hline & СОД, ум. од./л & \multicolumn{4}{|c|}{$1,23 \pm 0,02$} \\
\hline & ПАК, кМОЛЬ/л & \multicolumn{4}{|c|}{$288,64 \pm 4,27$} \\
\hline \multirow{4}{*}{$\begin{array}{l}\text { Ацетамінофрен } \\
7 \text { діб }\end{array}$} & ЦП, мг/л & $252,74 \pm 8,40$ & $263,96 \pm 0,94^{*}$ & $273,27 \pm 13,70$ & $277,38 \pm 11,69$ \\
\hline & КТ, мкат/л & $0,55 \pm 0,02^{*}$ & $0,54 \pm 0,01^{*}$ & $0,52 \pm 0,11^{*}$ & $0,50 \pm 0,07^{*}$ \\
\hline & СОД, ум. од./л & $1,96 \pm 0,32^{\star}$ & $1,87 \pm 0,19^{*}$ & $1,79 \pm 0,27$ & $1,72 \pm 0,18^{*}$ \\
\hline & ПАК, кмоль/л & $480,01 \pm 3,20 *$ & $491,55 \pm 4,52^{\star}$ & $517,24 \pm 8,96^{*}$ & $537,45 \pm 9,01^{*}$ \\
\hline \multirow[t]{4}{*}{ ЦД 2 типу } & ЦП, мг/л & $257,94 \pm 9,02^{*}$ & $275,46 \pm 0,44$ & $299,29 \pm 11,73$ & $307,23 \pm 10,72^{*}$ \\
\hline & КТ, мкат/л & $0,32 \pm 0,04$ & $0,29 \pm 0,01^{*}$ & $0,27 \pm 0,03$ & $0,25 \pm 0,02$ \\
\hline & СОД, ум. од./л & $1,59 \pm 0,16$ & $1,50 \pm 0,15$ & $1,42 \pm 0,25$ & $1,35 \pm 0,15$ \\
\hline & ПАК, кмоль/Л & $618,27 \pm 4,62^{*}$ & $635,30 \pm 3,42^{*}$ & $659,25 \pm 5,33^{*}$ & $682,63 \pm 6,28^{*}$ \\
\hline \multirow{4}{*}{$\begin{array}{l}\text { Ацетамінофрен } \\
\text { на тлі Цд } 2 \text { типу }\end{array}$} & ЦП, мг/л & $215,50 \pm 13,38$ & $230,56 \pm 1,00^{\star \#}$ & $242,61 \pm 14,85$ & $254,93 \pm 14,19$ \\
\hline & КТ, мкат/л & $0,79 \pm 0,24^{\star *}$ & $0,77 \pm 0,01^{\star *}$ & $0,75 \pm 0,15^{*}$ & $0,74 \pm 0,04^{* \#}$ \\
\hline & СОД, ум. од./л & $1,90 \pm 0,13^{*}$ & $1,84 \pm 0,14^{*}$ & $1,74 \pm 0,27$ & $1,68 \pm 0,19^{*}$ \\
\hline & ПАК, кмоль/л & $711,50 \pm 1,37^{* \#}$ & $743,25 \pm 4,02^{\star \#}$ & $775,86 \pm 4,10^{\star \#}$ & $783,95 \pm 5,24^{\star \#}$ \\
\hline
\end{tabular}

Таблиця 4 - Динаміка активності каталази і супероксиддисмутази в гомогенаті печінки щурів

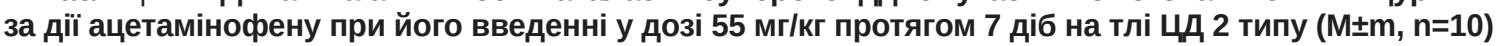

\begin{tabular}{|c|c|c|c|c|c|}
\hline \multirow{2}{*}{ Група тварин } & \multirow{2}{*}{ Показник } & \multicolumn{4}{|c|}{ Час після введення ацетамінофрену, доба } \\
\hline & & 1-ша & 3-тя & $5-\mathrm{Ta}$ & 7-ма \\
\hline \multirow[t]{2}{*}{ Контроль } & КТ, мкат/кг & \multicolumn{4}{|c|}{$59,53 \pm 1,43$} \\
\hline & СОД, ум. од./кг & \multicolumn{4}{|c|}{$4,09 \pm 0,13$} \\
\hline \multirow{2}{*}{$\begin{array}{l}\text { Ацетамінофен } \\
7 \text { діб }\end{array}$} & КТ, мкат/кг & $37,92 \pm 1,06^{*}$ & $40,42 \pm 1,02^{*}$ & $47,15 \pm 2,60^{\star}$ & $52,03 \pm 1,86^{\star}$ \\
\hline & СОД, ум. од./кг & $2,81 \pm 0,28$ & $2,97 \pm 0,30^{\star}$ & $3,26 \pm 0,23^{\star}$ & $3,45 \pm 0,33$ \\
\hline \multirow[t]{2}{*}{ ЦД 2 типу } & КТ, мкат/кг & $58,58 \pm 1,61^{*}$ & $61,20 \pm 0,84$ & $65,79 \pm 2,52^{*}$ & $72,39 \pm 2,09 *$ \\
\hline & СОД, ум. од./кг & $13,10 \pm 0,39 *$ & $13,79 \pm 1,17^{*}$ & $14,34 \pm 1,77^{*}$ & $14,82 \pm 1,43^{*}$ \\
\hline \multirow{2}{*}{$\begin{array}{l}\text { Ацетамінофрен } \\
\text { на тлі ЦД } 2 \text { типу }\end{array}$} & КТ, мкат/кг & $28,34 \pm 0,98^{\star \#}$ & $31,01 \pm 0,75^{\star \#}$ & $34,17 \pm 2,05^{\star \#}$ & $38,93 \pm 2,01^{\star \#}$ \\
\hline & СОД, ум. од./кг & $2,20 \pm 0,25^{\star}$ & $2,43 \pm 0,17^{\star}$ & $2,70 \pm 0,24^{\star}$ & $2,90 \pm 0,33^{\star}$ \\
\hline
\end{tabular}

ВИСНОВОК. Токсичне ураження ацетамінофреном на тлі ЦД 2 типу супроводжується суттєвими порушеннями орерментних компонентів системи антиоксидантного захисту, що мають компенсаторний характер і спрямовані на знешкодження продуктів вільнорадикального окиснення.

\section{СПИСОК ЛІТЕРАТУРИ}

1. Боднар П. М. Актуальні питання діагностики та лікування цукрового діабету / П. М. Боднар, Г. П. Михальчишин // Мистецтво лікування. - 2003. - № 1. C. $51-55$.

2. Буеверов А. О. Лекарственные поражения печени / А. О. Буеверов // Рос. мед. журн. - 2001. - 9, № 13. - C. 14.

3. Викторов А. П. Аллергические реакции на лекарственные средства: современные проблемы / А. П. Викторов // Новости медицины и фрармации. 2006. - № 16 (198). - С. 14-16.

4. Вплив ацетамінофену на активність процесів ліпопероксидації і стан антиоксидантної системи статевозрілих щурів-самок на тлі тривалого застосування прогестинів та естрогенів / І. Б. Івануса, І. М. Кліщ, І. 3. Кернична, Н. А. Василишин // Мед. хімія. -2011. 13, № 2 (47). - С. 56-62.
5. Івануса І. Б. Вплив тіотриазоліну на деякі показники антиоксидантної системи, вільнорадикального окиснення та ендогенної інтоксикації у щурів з токсичним ураженням ацетамінофеном на тлі тривалого введення естрогенів і прогестинів / І. Б. Івануса // Мед. хімія. - 2011. - 13, № 3 (48). - С. 75-80.

6. Кожем'якін Ю. М. Науково-практичні рекомендації з утримання лабораторних тварин та роботи 3 ними / Ю. М. Кожем'якін, О. С. Хромов, М. А. Філоненко. - К. : Авіцена, 2002. - 156 с.

7. Колб В. Г. Справочник по клинической химии / В. Г. Колб, В. С. Камышников. - М. : Минск, 1982. - 311 с.

8. Королюк М. А. Метод определения активности каталазы / М. А. Королюк, Л. И. Иванова, И. Г. Майорова // Лаб. дело. - 1988. - № 1. - С. 16-18.

9. Лапач С. Н. Статистические методы в медико-биологических исследованиях с использованием 
Excel / С. Н. Лапач, А. В. Чубенко, П. Н. Бабич. - К. : Морион, 2000. - 320 с.

10. Попов Т. Метод определения пероксидазной активности крови / Т. Попов, Л. Нейковска // Гигиена и санитария. - 1971. - № 10. - С. 89-93.

11. Чевари С. Роль супероксидредуктазы в окислительных процессах клетки и метод определения ее в биологическом материале / С. Чевари, И. Чаба й. Секей // Лаб. дело. - 1985. - № 11. - С. 678-681.

\section{REFERENCES}

1. Bodnar, P.M., \& Mykhalchyshyn, H.P. (2003) Aktualni pytannia diahnostyky ta likuvannia tsukrovoho diabetu [Current issues of diagnostics and treatment of diabetes mellitus]. Mystetstvo likuvannia - Art of Treatment, 1, 51-55 [in Ukrainian].

2. Buyeverov, A.O. (2001). Lekarstvennyye porazheniya pecheni [Drug lesions of liver]. Ros. med. zhurn. Russian Medical Journal, 9 (13), 14 [in Russian].

3. Viktorov, A.P. (2006). Allergicheskiye reaktsii na lekarstvennyye sredstva: sovremennyye problemy [Allergic reactions on drugs: modern problems]. Novosti meditsiny i farmatsii - News of Medicine and Pharmacy, 16 (198), 14-16 [in Russian].

4. Ivanusa, I.B., Klishch, I.M., Kernychna, I.Z., \& Vasylyshyn, N.A. (2011). Vplyv atsetaminofenu na aktyvnist protsesiv lipoperoksydatsii i stan antyoksydantnoi systemy statevozrilykh shchuriv-samok na tli tryvaloho zastosuvannia prohestyniv ta estroheniv [The impact of the activity of acetaminophen processes of lipid peroxidation and antioxidant system mature female rats against the backdrop of long-term use of estrogen and progestin] Medychna khimiia - Medical Chemistry, 2, 56-62 [in Ukrainian].

5. Ivanusa, I.B. (2011). Vplyv tiotryazolinu na deiaki pokaznyky antyoksydantnoi systemy, vilnoradykalnoho okysnennia ta endohennoi intoksykatsii u shchuriv z toksychnym urazhenniam atsetaminofenom na tli tryvaloho vvedennia estroheniv i prohestyniv [The impact of Thiotriazoline on some indicators of antioxidant system, free radical oxidation and endogenous intoxication in rats with acetaminophen toxic lesions on the background of long-term administration of estrogen and progestin] Medychna khimiia - Medical Chemistry, 3, 75-80 [in Ukrainian].

6. Kozhemiakin, Yu.M., Khromov, O.S., \& Filonenko, M.A. (2002). Naukovo-praktychni rekomendatsii z
12. Acetaminophen Toxicity in an Urban County Hospital / F. V. Schiodt, F. A. Rochling, D. L. Casey, W. M. Lee / New England Journal of Medicine. 1997. - 337, № 16. - P. 1112-1117.

13. Islam S. Nongenetic Model of Type 2 Diabetes: A Comparative Study / S. Islam, H. Choi // Pharmacology. - 2007. - № 79. - P. 243-249.

14. Islam S. Experimental rodent models of type 2 diabetes: a review / S. Islam, D. T. Loots // Methods Find Exp. Clin. Pharmacol. - 2009. - № 31 (4). - P. 249-261.

utrymannia laboratornykh tvaryn ta roboty z nymy [Scientific and practical advice on keeping laboratory animals and work with them]. Kyiv: Avitsena [in Ukrainian].

7. Kolb, V.G. \& Kamyshnikov, V.S. (1982). Spravochnik po klinicheskoy khimii [Handbook of Clinical Chemistry]. Moscow: Minsk [in Russian].

8. Korolyuk, M.A., Ivanova, L.I., \& Mayorova, I.G. (1988) Metod opredeleniya aktivnosti katalazy [Method of identification of catalase activity]. Lab. Delo-Laboratory Case, 1, 16-18 [in Russian].

9. Lapach, S.N., Chubenko, A.V. \& Babich, P.N. (2000). Statisticheskiye metody v mediko-biologicheskikh issledovaniyakh s ispolzovaniyem Excel [Statistical methods in biomedical research using Excel]. Kiev: Morion [in Russian].

10. Popov, T. \& Neykovska, L. (1971). Metod opredeleniya peroksidaznoy aktivnosti krovi [Method for determination of peroxidase activity of blood]. Gigiyena $i$ sanitariya - Hygiene and Sanitary, 10, 89-93 [in Russian].

11. Chevari, S., Chaba, I. \& Sekey, Y. (1985). Rol superoksidreduktazy $v$ okislitelnykh protsessakh kletki i metod opredeleniya ee $v$ biologicheskom materiale [The role of superoxide reductase in oxidative processes of the cell and the method of its determination in biological material]. Lab. Delo - Laboratory Case, 11, 678-681 [in Russian].

12. Schiodt, F.V., Rochling, F.A., Casey, D.L. \& Lee, W.M. (1997). Acetaminophen toxicity in an urban county hospital. New England Journal of Medicine, 337 (16), 1112-1117.

13. Islam, S., \& Choi, H. (2007). Nongenetic model of type 2 diabetes: a comparative study. Pharmacology, $79,243-249$

14. Islam, S., \& Loots, D.T. (2009) Experimental rodent models of type 2 diabetes: a review. Methods Find Exp. Clin. Pharmacol., 31 (4), 249-261.

О. Б. Фурка, И. Б. Ивануса, М. Н. Михалкив, И. Н. Клищ ТЕРНОПОЛЬСКИЙ ГОСУДАРСТВЕННЫЙ МЕДИЦИНСКИЙ УНИВЕРСИТЕТ ИМЕНИ И. Я. ГОРБАЧЕВСКОГО

\section{ИЗМЕНЕНИЕ НЕКОТОРЫХ ПОКАЗАТЕЛЕЙ АНТИОКСИДАНТНОЙ СИСТЕМЫ У КРЫС С ТОКСИЧЕСКИМ ПОРАЖЕНИЕМ АЦЕТАМИНОФЕНОМ НА ФОНЕ САХАРНОГО ДИАБЕТА 2 ТИПА}

\section{Резюме}

Вступление. Ацетаминофен оказывает дозозависимое действие на печень, степень поражения которой зависит от концентрации этого препарата в плазме. При приеме большого его количества 
(случайно или с суицидальными намерениями) в печени возникают массивные центролобулярные некрозы. Сахарный диабет является также одним из фракторов риска развития цирроза печени.

Цель исследования - изучить влияние ацетаминофена на фроне сахарного диабета 2 типа на основные показатели антиоксидантной системы в гомогенате печени и плазме крови крыс во временной динамике.

Методы исследования. Было проведено 2 серии эксперимента. В первой токсическое поражение ацетаминофеном вызывали путем однократного внутрижелудочного введения животным суспензии ацетаминофена в 2 \% растворе крахмала в дозе 1250 мг/кг массы тела (1/2 LD $\left.{ }_{50}\right)$, во второй - этой же суспензии в дозе 55 мг/кг. Негенетическую форму экспериментального сахарного диабета 2 типа моделировали путем однократного внутрибрюшного введения раствора стрептозотоцина из расчета 65 мг/ке, который разводили цитратным буфрером (рH 4,5) с предварительным интраперитонеальным введением никотинамида в дозе 230 мг/ке. Для контрольной группы использовали крыс с той же массой тела, которым вводили аналогичный объем растворителя (цитратный буфер с рН 4,5).

Результаты и обсуждение. Результаты эксперимента показали, что большую токсичность в организме подопытных животных вызывало введение ацетаминофена на фроне сахарного диабета 2 типа.

Вывод. Токсическое поражение ацетаминофеном на фроне сахарного диабета 2 типа сопровождается существенными нарушениями фрерментных компонентов системы антиоксидантной защиты, которые имеют компенсаторный характер и направлены на обезвреживание продуктов свободнорадикального окисления.

КЛЮЧЕВЫЕ СЛОВА: ацетаминофен; церулоплазмин; каталаза; супероксиддисмутаза; пероксидазная активность крови; сахарный диабет.

O. B. Furka, I. B. Ivanusa, M. M. Mykhalkiv, I. M. Klishch I. HORBACHEVSKY TERNOPIL STATE MEDICAL UNIVERSITY

\section{CHANGES OF SOME INDICES OF ANTIOXIDANT SYSTEM IN RATS WITH TYPE 2 DIABETES MELLITUS AND ACETAMINOPHEN TOXIC LESIONS}

Summary

Introduction. Acetaminophen has dose-dependent effect on the liver, which is the degree of damage depends on the concentration of this drug in plasma. When administration in large quantities of acetaminophen (accidentally or with suicidal intent) centrolobular massive necrosis occurs in the liver. Diabetes is also a risk factor for cirrhosis.

The aim of the study - to examine the effect of acetaminophen on main indices of antioxidant system in liver homogenate and blood plasma of rats with type 2 diabetes mellitus in time dynamics.

Methods of the research. We conducted two series of experiments. In the first series toxic lesion was caused by a single intragastric administration of acetaminophen suspension in $2 \%$ starch solution to animals in a dose of $1250 \mathrm{mg} / \mathrm{kg}\left(1 / 2 L D_{50}\right)$. In the second series the suspension of acetaminophen in $2 \%$ starch solution in a dose of $55 \mathrm{mg} / \mathrm{kg}$ was given, which corresponds to the highest therapeutic dose during 7 days. Non-genetic form of experimental type 2 diabetes mellitus was modeled by single intraperitoneal administration of streptozotocin solution in doses $65 \mathrm{mg} / \mathrm{kg}$ to rats, which was diluted by citrate buffer ( $\mathrm{pH}$ 4.5) with the previous intraperitoneal nicotinamide administration in doses of $230 \mathrm{mg} / \mathrm{kg}$. Rats with the same body weight, which were given the same amount of solvent (citrate buffer $\mathrm{pH} 4.5$ ), were used as the control group.

Results and Discussion. The results of the experiment show that a greater toxicity in the experimental animals causes the administration of acetaminophen on the background of type 2 diabetes.

Conclusion. Toxic lesion by acetaminophen in rats with type 2 diabetes mellitus is accompanied by significant violation of enzymatic components of the antioxidant system, have a compensatory nature and direct to neutralize of free radical oxidation products.

KEY WORDS: acetaminophen; ceruloplasmin; catalase; superoxide dismutase; peroxidase activity of blood; diabetes mellitus.

Отримано 22.02.17

Адреса для листування: І. Б. Івануса, Тернопільський державний медичний університет імені І. Я. Горбачевського, вул. Руська, З6, Тернопіль, 46000, Україна, e-mail: ivanusa@tdmu.edu.ua. 